\title{
Risperidone induced tardive dyskinesia
}

\section{Elakkya Kolanchinathan*, Dhanya Thirookaran Harichandran, Sujatha Mangattuvalappil Balakrishnan}

Department of Pharmacology, Government Medical College, Thrissur, Kerala, India

Received: 19 November 2020

Accepted: 29 December 2020

*Correspondence:

Dr. Elakkya Kolanchinathan,

Email: elakkiyakr277@gmail.com

Copyright: $($ ) the author(s), publisher and licensee Medip Academy. This is an open-access article distributed under the terms of the Creative Commons Attribution Non-Commercial License, which permits unrestricted non-commercial use, distribution, and reproduction in any medium, provided the original work is properly cited.

\begin{abstract}
Risperidone is an atypical antipsychotic drug which has been less likely to produce extrapyramidal symptoms. The aim of this case report is to illustrate that low dose risperidone may cause tardive dyskinesia. A 29 year old male patient with 9 year history of paranoid schizophrenia, developed tardive dyskinesia after receiving risperidone $2 \mathrm{mg}$ for 7 years. He had received small dosages of Haloperidol before the therapy of risperidone for short periods.
\end{abstract}

Keywords: Risperidone, Atypical antipsychotic, Tardive dyskinesia

\section{INTRODUCTION}

Risperidone is an atypical antipsychotic drug, a benzisoxizole derivative. ${ }^{1}$ It is a second serotonindopamine antagonist which was approved by FDA (1993) next to clozapine. ${ }^{2}$ It has potent and long lasting 5HT2 antagonism. ${ }^{3}$ It has similar clinical efficacy to typical antipsychotics like haloperidol, but with substantially fewer extrapyramidal side effects (EPS). ${ }^{3,4}$ But it has a high risk of tardive dyskinesia (TD) among atypical antipsychotics. ${ }^{5}$ It was found that annual incidence of risperidone induced TD is $5.3 \% .^{6}$ Most of the previous studies showed that risperidone produce TD only when the dose is more than $6 \mathrm{mg} /$ day. Present study reports a case of risperidone induced TD in young male patient was on risperidone of $2 \mathrm{mg} / \mathrm{day}$.

\section{CASE REPORT}

A 29 years old male patient, presented with Paranoid schizophrenia since last 9 years. Initially, he was treated with Haloperidol 5mg BD and had marked improvement but after 2 months, he developed symptoms of parkinsonism for which he was started on Trihexiphenidyl $2 \mathrm{mg} /$ day. There was an exacerbation of psychiatric symptoms after one year because of irregular treatment. At that time he was treated with risperidone, which was gradually increased from $1 \mathrm{mg} /$ day to 2 $\mathrm{mg}$ /day over a period of 6 weeks. This time also the patient showed improvement and risperidone $2 \mathrm{mg}$ was continued for the next six months as maintenance therapy. After seven years of lost follow-up with continuous risperidone therapy, the patient showed abnormal involuntary movements of both hands and dystonia of trunk. Abnormal involuntary movement scale (AIMS) examination was done and scored with 13 points (>3) and diagnosed as tardive dyskinesia. The patient was switched to clozapine $12.5 \mathrm{mg} /$ day, gradually increasing to $25 \mathrm{mg} /$ day and vitamin $\mathrm{E}$ also added. During next follow up, one month later there was no change in movements and clozapine was continued.

Table 1: Assessment of causality, severity and preventability of adverse drug reactions.

\begin{tabular}{ll}
\hline Assessment & Inference \\
\hline $\begin{array}{l}\text { WHO-UMC system and naranjo } \\
\text { algorithm causality assessment }\end{array}$ & Probable \\
\hline $\begin{array}{l}\text { Modified hartwig and seigel severity } \\
\text { scale }\end{array}$ & Moderate \\
\hline $\begin{array}{l}\text { Schumock and thornton preventability } \\
\text { scale }\end{array}$ & $\begin{array}{l}\text { Not } \\
\text { preventable }\end{array}$ \\
\hline
\end{tabular}




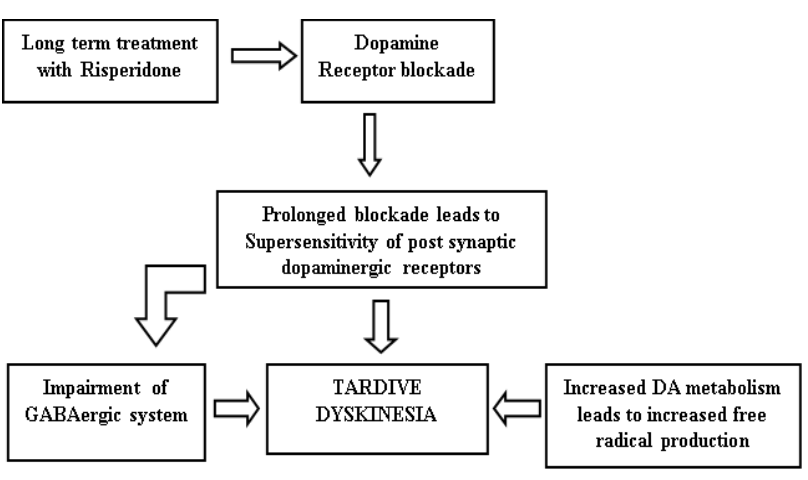

Figure 1: Schematic diagram of proposed pathophysiology of risperidone induced TD. ${ }^{11}$

\section{DISCUSSION}

Tardive dyskinesia (TD) is characterized byinvoluntary, choreiform, athetoid or rhythmicmovements of the tongue, jaw, trunk and extremities. ${ }^{7}$ Significant features in this case are that TD was caused by risperidone while he was on low dose of $2 \mathrm{mg} /$ day. Recognised risk factors for the development of tardive dyskinesia include a minimum cumulative exposure of three months to neuroleptics, increasing age, and female gender, high dosage of antipsychotics, concomitant administration of antipsychotics and antiparkinsonian drugs, early emergence of EPS and presence of affective symptoms. ${ }^{8,9}$

At the age of 29 our patient did not have any risk factors for developing tardive dyskinesia except early emergence of EPS and long term neuroleptic therapy. Even though this patient initially received haloperidol, he was exposed to risperidone for 8 years and there was no past history of dyskinesia. Hence the temporal relationship also suggests the diagnosis of risperidone induced TD. Majority of the studies explained that at a dose of $6 \mathrm{mg} /$ day risperidone may lose the balanced $5 \mathrm{HT}_{2} / \mathrm{D}_{2}$ blocking effect, resulting in more affinity for $\mathrm{D}_{2}$ receptors, thereby producing comparable EPS with classical antipsychotics. When the same dose continues for long time, it can lead to supersensitivity of $\mathrm{D}_{2}$ receptors in the nigrostriatal system producing tardive dyskinesia. ${ }^{10}$ In our study long term treatment with risperidone $2 \mathrm{mg} /$ day produced $\mathrm{TD}$ whether it may be due to similar mechanism.

\section{CONCLUSION}

Current study report a case of tardive dyskinesia caused by risperidone in a young male patient with a brief exposure to typical antipsychotics while he was on low dose of risperidone. The tardive dyskinesia still continuing even after one month of clozapine therapy. Clinicians should be aware of the possibility of patients developing TD though they are given the low dose risperidone.

\section{ACKNOWLEDGEMENTS}

Authors would like to thank Dr. Sumesh, Assistant Professor, department of psychiatry, for his guidance and support.

\section{Funding: No funding sources \\ Conflict of interest: None declared \\ Ethical approval: Not required}

\section{REFERENCES}

1. Ayd FJ, Pies RW. A specific comparison of the atypical antipsychotics. Adv Psychopharmacol. 1997;61-2.

2. Brecher M. Long term safety ofrisperidone. Eur Neuropsychopharmacol. 1996;6(Suppl.3):170.

3. Van Kammen DP, Marder SR. Dopamine receptor antagonists In: Kaplan HI, Saddock B, eds. Comprehensive textbook of psychiatry. Baltimore: Williams and Wilkins; 1995:1987-2022.

4. Song F. Risperidone in the treatment of schizophrenia: a meta-analysis of randomized controlled trials. J Psychopharmacol. 1997;11:65-71.

5. Owens DG. Extrapyramidal side effects and tolerability of risperidone: a review. J Clin Psychiatry. 1994;55(suppl):29-35.

6. Woerner MG, Correll CU, Alvir JM, Greenwald B, Delman H, Kane JM. Incidence of Tardive dyskinesia with risperidone or olanzapine in elderly. 2011;36(8):1738-46.

7. Cornett EM, Novitch M, Kaye AD, Kata V, Kaye AM. Medication induced Tardive dyskinesia. Ochsner J. 2017;162-74.

8. Kumar S, Malone DM. Risperidone implicated in the onset of tardive dyskinesia in a young woman. Postgrad Med J. 2000;76(895):316-7.

9. Van Os J, Fahy T, Jones P, Harvey I, Toone B, Murray R. Tardive dyskinesia: who is at risk? Acta Psychiatr Scand. 1997 Sep;96(3):206-16.

10. Jeste DV, Lacro JP, Bailey A, Rockwell E, Harris MJ, Caligiuri MP. Lower incidence of tardive dyskinesia with risperidone compared with haloperidol in older patients. J Am Geriatr Soc. 1999;47(6):716-9.

11. Shireen E. Experimental treatment of antipsychoticinduced movement disorders. J Exp Pharmacol. 2016;8:1-10.

Cite this article as: Kolanchinathan E, Harichandran DT, Balakrishnan SM. Risperidone induced tardive dyskinesia. Int J Basic Clin Pharmacol 2021;10:1967. 